\title{
Resenha \\ A imperfeição jornalística: a visão humanista de uma profissão em transformação
}

\author{
Celbi Vagner Melo Pegoraro \\ Universidade de São Paulo - celbipegoraro@usp.br \\ Jornalista, pós-graduado em Política e Relações Internacionais na Fundação \\ Escola de Sociologia e Política de São Paulo (FESP-SP) e mestrando em \\ Ciências da Comunicação na Escola de Comunicações e Artes da USP. Bolsista FAPESP.
}
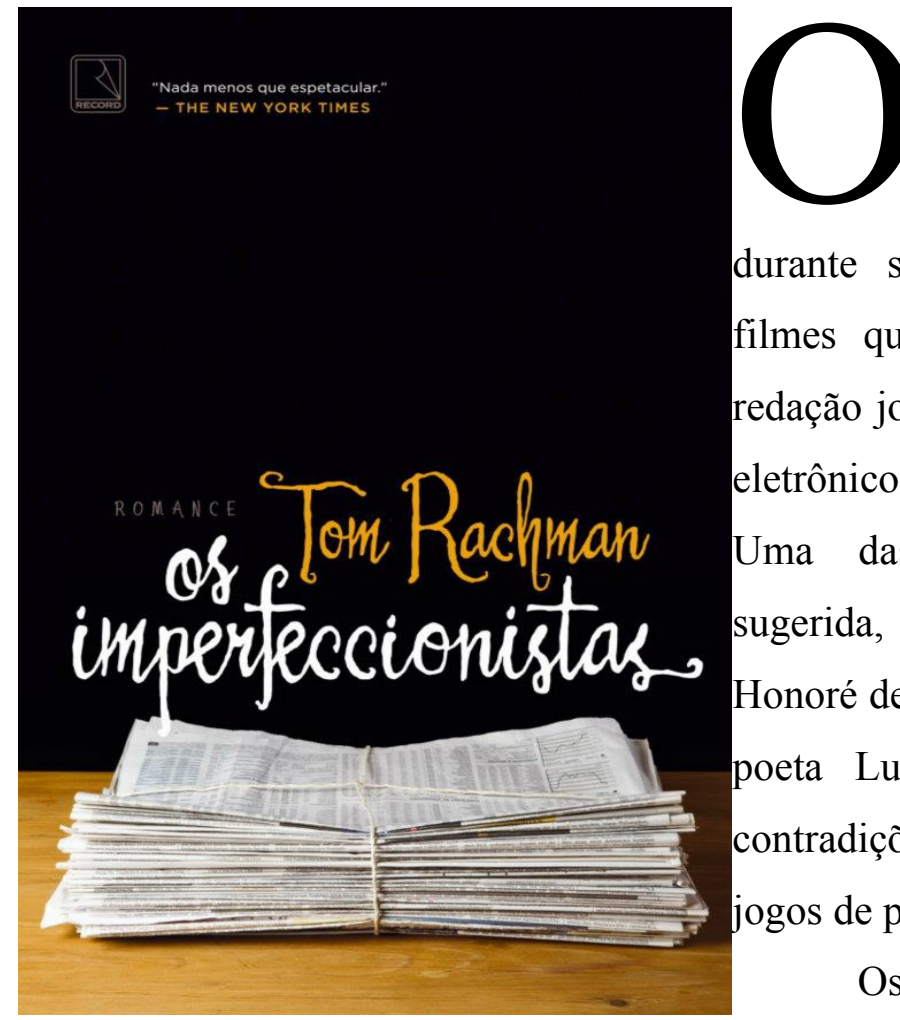

cursos de comunicação costumam apresentar aos futuros profissionais do jornalismo, durante sua formação, diversos livros e filmes que ilustram o cotidiano de uma redação jornalística de veículos impressos e eletrônicos, ou a própria história jornalística. Uma das obras clássicas, geralmente sugerida, é o livro "Ilusões Perdidas" de Honoré de Balzac, descrevendo a história do poeta Lucien de Rubempré vivendo as contradições da atividade jornalística e os jogos de poder na Paris do século XIX.

Os jornalistas podem ter uma visão contemporânea da rotina de trabalho no romance cômico Os Imperfeccionistas, primeiro livro do jornalista inglês Tom Rachman. A história é ambientada em Roma, e boa parte dos personagens são funcionários de um jornal norte-americano instalado na capital italiana. O fictício jornal foi fundado por um magnata americano chamado Cyrus Ott, numa possível alusão ao nome de Adolph Ochs (fundador do existente e tradicional jornal The New York Times). Em 2004, quem cuida do jornal descrito no livro é o neto do magnata, Oliver, que gerencia as operações com menos cuidado do que trata de seu cão basset, Schopenhauer, o centro de suas atenções. 
Rachman estrutura o livro em uma série de histórias em que cada funcionário da redação é foco de um capítulo (um leitor também é citado) e, ao longo da obra os fatos se tornam entrelaçados resultando, enfim, num panorama em que todos os membros da redação são vistos por diversos ângulos. Somos apresentados a uma variedade de personalidades inimagináveis a uma primeira vista, mas que ganham imperfeições em sua rotina de constantes desafios, angústias e desilusões, tendo diante de si uma perspectiva nebulosa.

Os capítulos, em forma de contos, apresentam curiosas situações envolvendo os funcionários, cujas características de vida e de trabalho certamente soam um tanto comuns para um jornalista que já tenha convivido com dezenas de colegas. Temos o obtuarista que vive uma busca constante pelo morto ideal, enquanto pensa em sua querida filha; o indispensável e chato editor responsável pela revisão gramatical que dispara memorandos corrigindo erros e condenando expressões inadmissíveis, que são solenemente ignorados pelos colegas; o correspondente que se vê abandonado pela chefia; o repórter veterano casado quatro vezes que se vê envolvido num problema envolvendo traição de fonte; e a editora que suspeita que a equipe conspira contra ela. Há também a editora executiva viciada em trabalho que não larga por um segundo seu Blackberry; temos a diretora responsável por demitir e enxugar cargos que recebe da redação o irônico apelido de "Contas a Pagar"; e também uma editora quarentona que odeia o serviço e teme ser demitida.

De um modo geral, o autor parece demonstrar que a profissão de jornalista aparenta perder ainda mais sua influência e o pouco de glamour implícito. Entre as diversas situações envolvendo os membros da redação, o autor constrói uma sequência paralela de histórias, desta vez focada na família Ott, proprietária do jornal. Podemos observar que as relações de poder diminuem drasticamente ao longo das três gerações, culminando com o jovem e inseguro Oliver Ott, que não parece ter o menor talento para os negócios. Essa situação tem referência em acontecimentos reais, em que descendentes das famílias proprietárias de jornais se veem forçados a vender parte ou todo o negócio, ou a reformular todo o processo de produção com ajuda de gestores, o que, em muitos casos, resulta em demissões e redução gradativa da qualidade do material jornalístico produzido.

Um importante aspecto da obra de Tom Rachman é o contexto em que ocorrem as histórias, o que eleva a importância da leitura e da reflexão de uma carreira atualmente em transformação. $\mathrm{O}$ contexto se divide em duas faces. A primeira é 
relacionada à época em que o livro foi escrito, tendo em vista a grave crise enfrentada pelos grandes jornais norte-americanos no biênio 2008 e 2009. Dezenas de jornais foram fechados, centenas de jornalistas ficaram desempregados ou se viram forçados a trocar de área e grandes jornais tradicionais como o Chicago Herald, o Boston Globe e o The New York Times sofreram turbulências financeiras, além de queda de faturamento e de influência.

O autor também trabalha o tema da revolução digital nos meios de comunicação. Esta segunda face do livro demonstra o impacto que a internet possui na produção jornalística e quanto esta colabora para as situações vivenciadas pelos jornalistas em sua rotina diária. Não há a problematização de forma direta, mas é perceptível que as novas formas de comunicação mudaram o modo como a informação é produzida e distribuída, em seus aspectos positivos e negativos.

Os novos paradigmas de espaço e tempo alteraram de forma sensível a produção jornalística. Não há apenas a reflexão pela própria qualidade de vida do profissional, mas existe a problemática da produção da notícia com maior rapidez, muitas vezes em detrimento da qualidade jornalística. A internet, por meio das redes sociais, demonstra que a mídia tradicional necessita repensar valores e formas de produção. A internet tornou a transmissão de notícias mais eficiente, cabendo ao jornalismo tradicional o aprofundamento dos assuntos como forma de legitimar as informações. Por ser um romance, o leitor tem uma noção bastante razoável das questões complexas da área e certamente a obra contribui para uma reflexão sobre a formação jornalística, que ainda carece de uma reformulação que inclua as novas ferramentas da era da convergência e os novos desafios impostos por processos de comunicação em constante transformação.

\title{
Referência Bibliográfica
}

RACHMAN, Tom. Os Imperfeccionistas. São Paulo: Editora Record, 2012. 384p. Tradução de Flávia Carneiro Anderson

\author{
Este artigo e todo o conteúdo da Estudos em Jornalismo e Mídia estão disponíveis em \\ http://www.periodicos.ufsc.br/index.php/jornalismo/index
}

Estudos em Jornalismo e Mídia está sob a Licença Creative Commons. 